\title{
Territorio de signos y lenguajes de la ciudad de Málaga: la pintura mural
}

\author{
Rosario Camacho Martínez \\ Catedrática de $\mathrm{H}^{a}$ del Arte \\ Universidad de Málaga
}

Eduardo Asenjo Rubio

Centro de Documentación del IAPH

\section{Resumen}

El proceso evolutivo de una civilización, a lo largo de la historia, se ha evidenciado a través de unas constantes materiales que, con el devenir de los tiempos, se han convertido, luego de asumirlas, en un legado universal, referente incuestionable de la memoria del hombre, entendido éste como productor de objetos culturales.

En los tiempos actuales, los estudios cromáticos de la ciudad, y en especial de ámbitos restringidos, como los Centros Históricos, o los Conjuntos Históricos están generando, cada vez, más una visión escueta de la valoración del patrimonio urbano, convirtiendo lo histórico en cápsulas reducidas, en vez de espacios de fronteras.

La problemática que se plantea en estos momentos sobre este hecho material de la cultura en la ciudad de Málaga, estriba en el escaso conocimiento, no sólo de ese patrimonio como un bien heredado, sino como un posible agente de cohesión e identidad en determinados espacios urbanos.

Sin embargo, la ausencia de una metodología, en cuanto a la determinación de los criterios de intervención más adecuados, la falta de un debate en términos conceptuales y propositivos respecto a la arquitectura que porta estas escenografías efímeras, ponen a la pintura mural en una diatriba de difícil sostenimiento, pues los problemas son muchos: deterioro, especulación, la fragilidad de los materiales frente a la fuerte agresión del medio, lo que provoca una pérdida acelerada de este significativo patrimonio, a la vez que una parca mirada hacia el mismo.

En definitiva, apenas contamos con dos o tres ejemplos intervenidos desde la madurez y la reflexión, y cuando se ha tenido la oportunidad de apostar por la continuidad de esos criterios, la burocracia y los intereses políticos han caído como un pesado lastre, rompiéndose la cadena de transmisión entre la sociedad y el patrimonio no desvelado.
Este artículo es una invitación a la lectura de las arquitecturas pintadas desde su definición, caracterización, así como un examen revisionista, después de diez años, para valorar la situación real en la que nos hallamos, es decir, estamos defendiendo para proteger $\mathrm{o}$, protegiendo para conservar.

\section{Palabras clave}

Patrimonio / Territorio / Arquitecturas / Pintura Mural / Tipologías / Ornamentación.

\section{Introducción a la reflexión}

Los lugares de hábitat del ser humano, las distintas apropiaciones que ha realizado del espacio en el que se ha desenvuelto a lo largo de la historia, se han caracterizado por la relevancia material de una multiplicidad de fragmentos de la memoria ignota, leída y entendida por la sociedad actual, a modo de huella testimonial. Esos fragmentos localizados en unos enclaves, el territorio, en su más primaria acepción han querido legarnos significados extensos, de horizontes culturales, casi inabarcables por el hombre. Si hay algo que ha marcado la pauta diferenciadora entre una civilización y otra, sin duda, la materialidad de sus construcciones ha venido a ser uno de los rasgos más esclarecedores.

Toda vez que los asentamientos dejaron de ser itinerantes, los grupos tribales evolucionaron hasta constituirse en sociedades, apareciendo las ciudades, instaladas en un medio geográfico, determinante por muchos de sus agentes. A partir de ahí, el ser humano ha ido condicionando el espacio a sus necesidades, construyendo y destruyendo, sedimentando, reutilizando y colmatando elementos materiales de esas culturas. En todo ese largo proceso ha dejado huellas de esa presencia que se han convertido en componentes diversos, representativos de esa cultura: restos de inmuebles, a veces casi completos, ajuares y muebles de distinto signo.

La aproximación al estudio de esas civilizaciones ha consistido, inicialmente, en la caracterización de unos materiales, señas inequívocas de pertenencia, asociados a un medio geográfico. Conmensurar cada una de esas señas resulta un esfuerzo titánico, y en unos parámetros tan vastos como el territorio, que nos invita a detenernos en una realidad territorial más próxima, como el contexto urbano.

La ciudad de Málaga nos ofrece ese contexto que permite analizar la pintura mural del siglo XVIII que 
consideramos como un lenguaje perfectamente trabado con su soporte, la arquitectura, para adentrarnos en su caracterización, lo cual posibilita justificarla como una de las partes más destacadas, menos conocidas y valoradas del patrimonio de la ciudad, para pasar, por último, a plantear la problemática de su conservación.

Esa secuencia cronológica y territorial de la pintura mural seleccionada en Málaga ha generado paisajes en continua transformación, llegándonos en la actualidad, muchos de ellos completamente desdibujados, algunos excesivamente intervenidos por el hombre, y otros escasamente valorados por la sociedad. Pero en todos ellos, lo material, lo concreto y tangible de la cultura siempre ha estado latente, a través de la forma, convertido en signo y recuperado desde la articulación del lenguaje, como la materialidad de esas culturas que han traspasado con éxito el paso del tiempo, constituyéndose, en definitiva, en una de las muestras más significativas del pasado híbrido de una ciudad, como Málaga y, por ende, de un testimonio más de la riqueza multicultural de la Comunidad Autónoma de Andalucía.

De casi todos era conocido el fragmento de lienzo de muralla conservada junto a la antigua zanja de la calle Carretería. Sin embargo, la llamada de atención y el dispositivo que la administración municipal va a crear en torno a él, lo convierte decididamente en otro signo más del elenco de la nueva cultura de la conservación a la que pertenecemos. En poco tiempo va a contar con un montaje expositivo que nos ayudará a interpretar otras claves menos conocidas de la ciudad patrimonial. Indudablemente este elemento del patrimonio ha nacido bajo el signo de la fortuna, a diferencia de otros. No obstante, este proyecto no nace de una visión global, tan ansiada, del patrimonio cultural, sino todo lo contrario, es una pieza más en la construcción de un rompecabezas. Prueba de ello es el número bastante significativo de inmuebles que están desapareciendo en la ciudad a un ritmo acelerado, y escasamente justificado. La pintura mural no es fragmento aún, a pesar del fuerte menoscabo producido en los últimos diez años. Hoy día, casi se puede hablar en términos de totalidad, aunque la política municipal todavía tiene que hacer un esfuerzo importante, lo está realizando, para su recuperación. Esta postura pasa la mayoría de las veces, primero, por el conocimiento y valoración de su patrimonio, segundo, el establecimiento de estrategias, y, por último, la distribución equitativa de los medios e instrumentos que posee.

No obstante, nosotros queremos expresar y transmitir en este artículo dedicado a la pintura mural de las fachadas de los inmuebles, en un territorio acotado y urbano, como es la ciudad de Málaga, la magnitud de esas esforzadas construcciones ilusorias, sin perder nunca la relación y referencia con otros contextos territoriales andaluces, como Granada, Sevilla, o Cádiz, teniendo en cuenta que todos ellos presentan una especial singularidad morfológica, diferenciada entre unas y otras, por factores geográficos, eco- nómicos, además de los materiales minerales, las escalas de sus edificios, junto a motivos de desarrollo, y la capacidad de lograr y provocar en el paisaje urbano otras miradas, desde una especial posición, como es la del historiador del arte, versus lector de imágenes, con una carga patrimonial cada vez más acentuada en ese acercamiento a la realidad.

De este modo, queremos presentar una mirada amplia sobre la especial situación de este patrimonio, desde su definición, la significación, la ubicación respecto a otros patrimonios, como las torres vigías y los castillos, la valoración social, la riqueza singular de sus materiales, la caracterización, y después de todas estas indagaciones, cuestionarnos ante qué eslabón de la cadena nos encontramos a la fecha de hoy: seguir defendiendo o continuar conservando, pero, ¿de qué modo y con qué criterios?

La pintura mural la entendemos y definimos como un rasgo caracterizador de la cultura, de la expresión del hombre en un período cronológico que arranca en los albores de la civilización, pero que en cada período de la historia ha servido para instrumentalizar significados diversos de los contenidos expresados desde ese medio, caracterizando esas etapas, teniendo en cuenta el sentido general y ubicación de ese repertorio ornamental. Pero, sobre todo, y lo que creemos más interesante es la capacidad de aportar renovadoras lecturas del pasado urbano, enriqueciéndolo, o del medio geográfico en el que se instala, más allá de la monumentalidad de las escenografías que configuran los espacios de la ciudad: iglesias, catedrales, palacios y alcazabas. Un último matiz nos permite enunciar que la estratificación cultural en las ciudades actuales plantea el problema de la selección. Ésta debe implicar ante todo madurez en la reflexión del modelo de ciudad cultural que se quiere crear, pero sobre todo lucidez en los criterios selectivos. Para que esto se cumpla se necesita, simplemente, conocer para valorar. Y en ese sentido, la trasposición de esta máxima sigue siendo, con ligeros matices, el inventario, al que nos referiremos con posterioridad.

En la profesión del historiador del arte se encuentran múltiples resortes para diversificar y enriquecer la práctica profesional, y uno de ellos, atribuido tradicionalmente, ha consistido en la valoración en términos globales de la obra de arte. Con todo, en estos últimos años se asiste a una política educativa, cada vez más convergente, que recaba de la interdisciplinariedad un aparato metodológico para unificar criterios de intervención, pero que, además, entendemos no sólo como un aporte parcial de la disciplina, sino también, como una transferencia de conocimiento entre unas y otras. De este modo, las pinturas murales que aparecen en un contexto urbano, como el de Málaga, marcado por la fuerte vorágine renovadora de su caserío, tienen que hacer frente en los años ochenta desde nuestra profesión a su descubrimiento, para crear y lograr una llamada de atención institucional y social. Nuestra misión es desvelar lo sobresaliente de este hecho material de la cultura del siglo XVIII, que es la que ha prevalecido en la ciu- 
dad de Málaga al exterior de los inmuebles, transmitiendo unos conceptos básicos a la sociedad y a los profesionales, arquitectos y restauradores, entre otros, para su posterior intervención. Parecía que únicamente estábamos llamados a poner el acento sobre la clasificación, periodización y significado de las imágenes, pero ahora también estamos en disposición de recomendar e insistir las formas en las que deben ser recuperadas, como fruto de la observación y de la práctica dispar de las intervenciones acometidas sobre estos elementos durante algo más de dos décadas.

Cada ciudad encuentra unos instrumentos de valoración partiendo de su desarrollo histórico, unos recursos expresivos heredados, y Málaga a diferencia de otras geografías andaluzas posee una amplia gama de posibilidades respecto a la valoración de la pintura mural como agente de cambio del panorama urbano, permitiendo ubicarla en uno de los lugares preeminentes; empero, estos recursos deben ser puestos a disposición de la sociedad, para que ese patrimonio sea decididamente social, por lo que ésta deberá movilizarse, tomando conciencia, reclamando su protección. Hasta la fecha, desde el equipo que compone este proyecto, hemos inventariado, estamos, todavía, en fase de análisis de los resultados, hemos creado un producto de comunicación, además de estar en contacto con la administración autonómica y municipal, colaborando de forma conjunta. En todas estas acciones nuestras reflexiones han tenido como meta transmitir este conocimiento a la sociedad, como depositaria y legítima heredera. Aún queda un ingente trabajo por hacer, pero si no se llega a un compromiso de no-agresión de las áreas homogéneas de pintura mural que existen en la ciudad, ¿qué recabaremos del pasado para rehabilitarlo y transferirlo, como memoria a la sociedad?

\section{La configuración de un lenguaje}

En toda esta reflexión sobre la importancia de la pintura mural, y luego de otras lecturas, resulta obvio precisar determinados términos, parámetros claros que ayuden a definir y transmitir este caudal de información. La propia estructura del título de este artículo nos lo exige, pero también la amplia presencia en el suelo urbano de la ciudad de Málaga, las similitudes de los motivos ornamentales, lo compacto de la secuencia cronológica en la que nos movemos, así como la escasa atención, y la irregularidad en los criterios de intervención, lo justifica. Por todo ello, hemos querido adentrarnos en lo esencial del significado de este título, basándonos en una serie de conceptos, que creemos oportunos definir inicialmente, además de la necesidad de incidir en la singular articulación de un lenguaje netamente caracterizado por la recurrencia a un material efímero, y trasgresor de la forma clásica en la construcción de espacios.

Signo: Es la unidad básica de un mecanismo mayor: el lenguaje. Se presenta como el elemento caracteriza- dor y formalizador de un repertorio heterogéneo, y nos remite a unas características de índole diversa, que estudia la unidad, a diferencia del lenguaje que se orienta hacia la comprensión de los signos.

Lenguaje: Es la unión de signos que permite el acceso a un significado. Posibilita el acercamiento a una lectura global en unos contextos territoriales. Sus características formales, materiales y significativas lo convierte en las expresiones más claras e identificativas del desarrollo instrumental de un grupo cultural. Está sujeto a modificaciones.

Territorio: El territorio, en definitiva, en su más amplia definición, constituye ámbitos espaciales de diferente alcance. Hay variedad de territorios, nosotros nos referiremos al urbano, aunque haremos una pequeña conexión con otros, a modo de ejemplificación en la construcción del lenguaje, de tal forma, que ninguno puede sustraerse a éste, que alberga la obra del hombre, reconocible, a través de algún testimonio material.

Y son las especiales características morfológicas las que han determinado lenguajes que se han articulado de diferentes formas. La pintura mural es uno de ellos, repartidos por todo el territorio andaluz, una constante en la configuración de muchos de sus paisajes urbanos, que precisa mayor atención.

En Bases para una Carta sobre Patrimonio y Desarrollo en Andalucía (1996), se indica, que además de ser de dimensiones considerables, acoge a la diversidad morfológica del territorio andaluz: urbano, campiña y vega, costero e interior, pero también otros, más allá del límite administrativo preciso '.

Añadimos que los bienes culturales que se localizan en estos territorios inciden y responden directamente sobre las formas en las que el ser humano se ha desenvuelto a lo largo de la historia. En ese sentido, hay que recalcar de forma positiva, que hoy en día la elaboración de un documento con aspiraciones territoriales no deja a un lado los elementos patrimoniales que se encuentran inmersos en él. Son varios los planes de desarrollo territorial elaborados por distintas Consejerías (Obras Públicas, Turismo, Agricultura y Medioambiente), así como las directrices que vienen desde Bruselas, en donde lo territorial contempla al patrimonio, como un aspecto relevante en las normas que rigen sus actuaciones.

Paisaje urbano: Es una secuencia de distinta magnitud al territorio, más acotado, a la vez que una naturaleza actuada por el hombre, pero también un punto de encuentro y conocimiento de su evolución en un momento dado, transmitido y referenciado a través de los numerosos escritos y libros que en ocasiones la mirada de los viajeros ha proyectado.

Esa identificación del lenguaje en un espacio desde la apoyatura de unos signos explícitos forma parte de una estructura semántica mayor, configurando al final un territorio a modo de texto, en donde se cuentan 
hechos, acontecimientos del hombre, y que, en última instancia, ha generado diversos paisajes culturales, seña inequívoca de la identificación del patrimonio cultural.

De este modo, a lo largo de la historia de las civilizaciones, éstas han reforzado su presencia sobre un ámbito territorial predeterminado. Su acción sobre el territorio les ha permitido imprimir carácter a distintos aspectos, que han ido conformando la cultura. Se ha dicho no hace mucho tiempo, respecto a la relación del territorio con el ser humano, que existían dos tipos de hombres: del interior y de la costa. Desde entonces, el paso del hombre ha provocado la construcción de paisajes y fisonomías, que han ayudado a vertebrar el territorio, otorgándonos unas características específicas para su reconocimiento. $Y$ es ahí en donde ha dejado su huella, entendida ésta como el grado máximo alcanzado por una cultura, llegando hasta nosotros con mayor o menor fortuna, o mejor, digamos que esa fortuna ha estado profundamente marcada por el proceso valorativo de la comunidad actual. Algunos de ellos han sobrevivido a la constante transformación de los usos y funciones que tuvieron en origen, convirtiéndose en hitos de la memoria colectiva, en definitiva, en signos de pertenencia. Sin embargo, otros signos de la cultura, que forman nuestro patrimonio, han superado la barrera del tiempo, es decir, han permanecido de manera tangible, pero no han logrado ser resignificados por la sociedad en ese proceso de continua valoración de nuestro legado, dejando el rastro de una huella, que indefectiblemente parece estar llamada a desaparecer².

En este proceso de construcción del signo y la articulación del lenguaje se comienza a descubrir en Málaga la pintura mural, en unos momentos, en los años ochenta, cuando la propia ciudad vive inmersa en otros procesos de distinto alcance: proyección de la ciudad, desarrollo que lleva a intervenciones inapropiadas, escasa valoración del patrimonio no monumental, etc. En esos años va a perderse un ingente número de signos, que daban carta de naturaleza a ese lenguaje, quedando parcialmente mutilado en determinadas áreas de la ciudad. Esa pérdida viene dada por una exigua ubicación conceptual del patrimonio, así como de una práctica poco reflexiva del mismo, frente a otros documentos, como el Plan General de Ordenación Urbana, cuyas actuaciones estaban dirigidas, principalmente, a la salvaguardia de lo monumental, frente a la labor compiladora de ese documento, que debía convertirse, en esencia, en un contenedor y exponente de todas las manifestaciones culturales producidas por el hombre en la ciudad de Málaga.

Consecuencia del desajuste entre la ciudad histórica y la necesidad de su rehabilitación fue la malograda intervención llevada a cabo en los barrios de la Trinidad y el Perchel, después de haber realizado un Plan Especial muy valorado, pero la no-aplicación inmediata, unido a las diversas modificaciones, supuso el desmonoramiento, lo que ocasionó que se desarticulara la unidad, no valorando las tipologías constructivas, la necesidad de que la población permaneciera in situ, etc, viendo en el acuciante deterioro y degradación de la zona una vía idónea para intervenir en los años noventa; sin embargo, en vez de actuar indagando desde las experiencias de otras áreas igualmente degradadas -en el propio territorio español o en el exterior-, se orientó por el camino de la destrucción, dejando pequeños testigos inconexos, islas frente a un mar de culturas.

A pesar de todo esto, la sociedad comienza a hacerse eco de su conocimiento y problemática, de una forma más evidente, en esos años iniciales, cuando el Diario Sur dedica algunos reportajes, tomando como base lo que el Padre Lamothe (+ 2000) iba descubriendo en el Perchel. Pero, no es hasta el año 1992, cuando comienza a realizarse una primera clasificación de estas pinturas, así como una interpretación, con lo cual el signo en una lectura más amplia ya se percibe como lenguaje, siendo esta la pauta orientadora, es decir la de ser lenguaje dentro de unos parámetros cronológicos precisos, la que va a servir de guía para los estudios posteriores ${ }^{3}$.

Indudablemente, el territorio urbano constituye una amalgama de signos, modernos y contemporáneos, de todo tipo, no obstante, a nosotros nos interesan aquellos que informan de valores el patrimonio. A veces, la relación que se plantea entre el interlocutor y el objeto de comunicación se basa en su desconocimiento, como sucede con la pintura mural de Málaga; sin éste, y sin su valoración no se podría devolver a la sociedad un producto elaborado, es decir, aquel que nos permita a través de distintos recursos, interpretar, poner a disposición de la sociedad, de manera más clara, unos significados para hacer más accesible ese patrimonio. Por lo tanto, y a pesar de los precedentes, nos encontramos, en la actualidad, ante un momento de bonanza en la valoración de la cultura por la ciudadanía, pues desde comienzos de los años noventa, acentuándose a partir de la mitad de esa década, asistimos a un momento interesante en la evolución social, marcado por el fuerte consumo cultural, la diversificación en la estacionalidad de los períodos vacacionales, y una mayor dedicación al ocio y al disfrute de la cultura, como marcos generales ${ }^{4}$.

Sin lugar a dudas, la dimensión espacial de los territorios de la cultura, de forma genérica, se convierte en un importante conjunto de lugares, en donde se interactúa e interrelaciona al mismo tiempo, dejando una fuerte impronta. Bajo esta percepción, el lenguaje, como estructura básica de la articulación del patrimonio en el territorio, se enriquece, a la vez que diversifica sus contenidos y significados.

Cuando hablamos del signo, lo hacemos obviamente en singular, aunque éste comporte diversos significados. Es el caso de una iglesia, un castillo, la casa - la plaza de un determinado lugar. El papel jugado a lo largo de su historia determinará diferentes apreciaciones del hecho urbano, así como la forma en la que van a ser percibidos por la comunidad. La lec- 


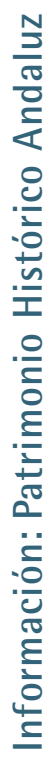

tura que hagamos de esos signos, dependiendo de su amplitud y la manera de trabarse con el resto formará parte de esa unidad mayor: el lenguaje.

De esta forma, y a modo de ejemplo de la construcción de un lenguaje en el territorio urbano diremos que los sepulcros parietales de la familia Sánchez Dalp de la Iglesia Omnium Sanctorum de Sevilla, son signos evidentes de ese lenguaje, referente incuestionable de una etapa cultural -siglos XV y XVI-, dentro de un contexto urbano, en el momento en que

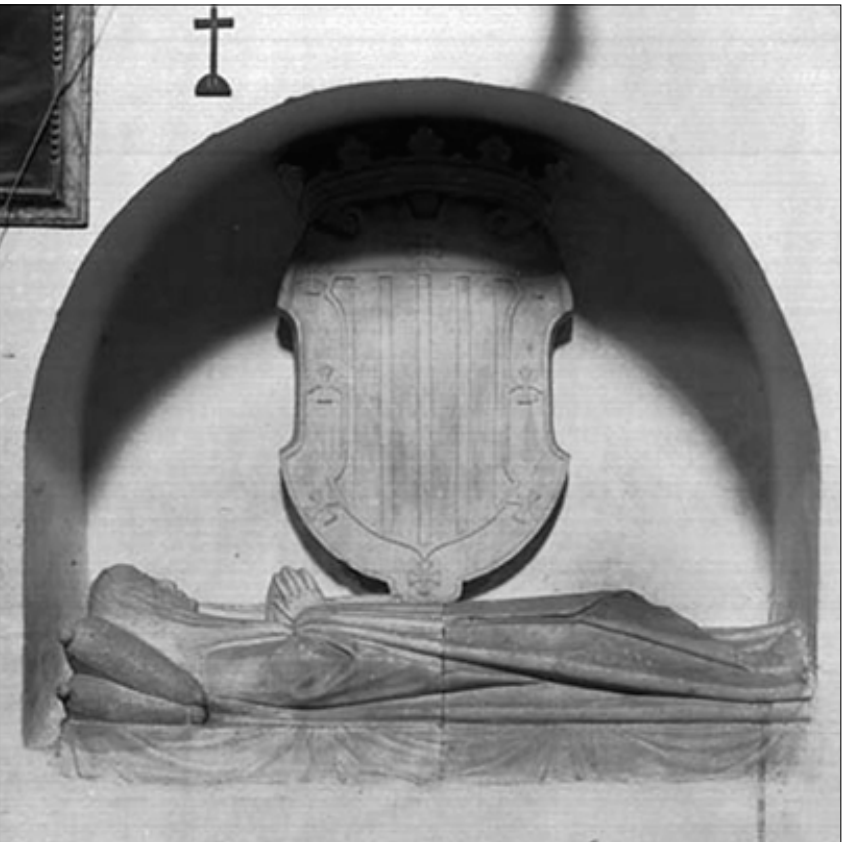

Foto I: Sevilla. Iglesia parroquial Ommium Sanctorum

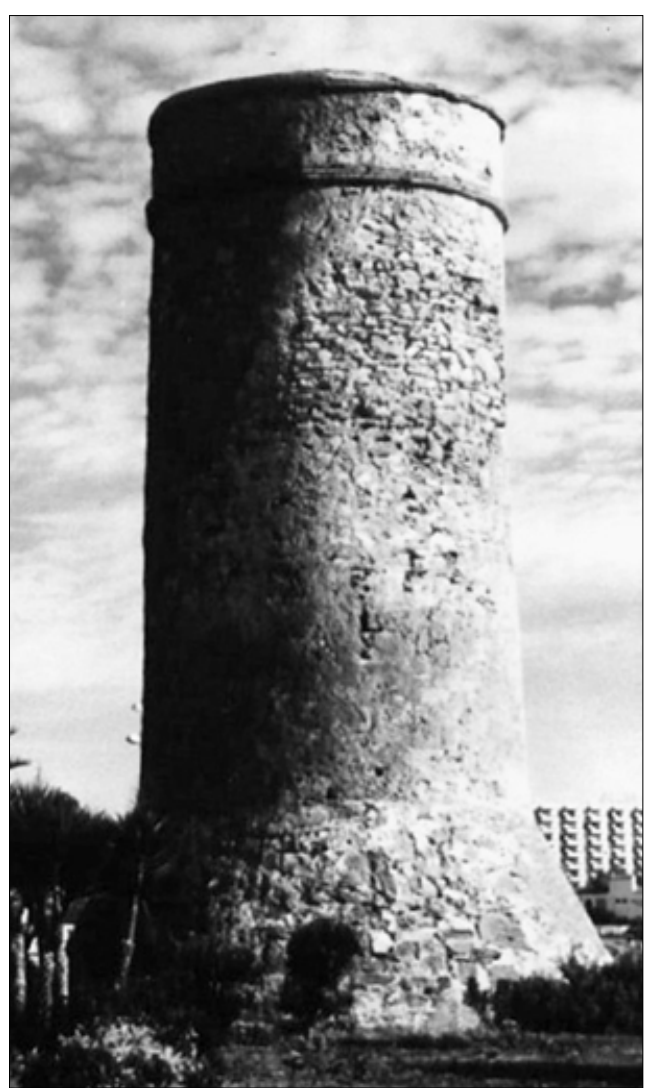

son percibidos en unión a otros. Acerquémonos a ellos, como signos y como lenguaje.

Cada uno de estos sepulcros es un signo en sí mismo, pues presentan unos valores y unas características propias. Se convierten en la imagen representativa de una familia para perdurar, con distinta significación según el período histórico, y por otro lado, son objetos valorados entre los bienes que alberga esa iglesia por parte de la comunidad. Ese proceso valorativo temporal de apreciación los convierte en elementos singulares que provocan variadas percepciones. Representan al mismo tiempo un lenguaje, es decir, la manifestación de una creencia dentro de la cultura, a caballo entre la Edad Media y el Renacimiento, que junto a las diferentes formas de enterrarse, ya sean éstas, laudas, sepulcros parietales, bóvedas de enterramiento, panteones, cementerios, etc., de los distintos estamentos sociales se convierten en un lenguaje más amplio que permite aprehender a esa cultura en distintos ámbitos espaciales y cronológicos, a la vez que constatamos su evolución formal, material y espiritual (Figura I) ${ }^{5}$. Sin embargo, esos signos, y la estructura lingüística, a veces son presentados de forma que pasan desapercibidos, como, de hecho, sucede con la pintura mural, pero con otra problemática que pone el acento en la fuerte contaminación, polución y suciedad, los cambios en el gusto de los propietarios que los lleva a eliminar de raíz decoraciones enteras, y la dificultad económica de su conservación.

En algunas ocasiones, el lenguaje de ciertos territorios ha perdido sus signos que hacían de nexos, quedando desarticulados, comportando otros significados, en definitiva, pasando a otros contextos con diferentes connotaciones. Del mismo modo, ese lenguaje inmerso en un amplio territorio, es interactuado de múltiples maneras, debatiéndose entre el aporte significativo originario y la permanencia actual.

Así, Torre Bermeja, una de las torres vigías de la costa malacitana es un elemento inequívoco del patrimonio cultural, que forma parte de un entramado de comunicaciones, con otras torres, que jalonan el territorio interior y costero, que en última instancia establecían un código de señales. Este sistema permitía conectar distintos territorios para su comunicación, actuando como eje vertebrador del mismo. En la actualidad esos signos, la mayoría de las veces, se presentan seccionados. Su significado como elemento eficaz de un intenso sistema de comunicación se pierde, convirtiéndose en otra suerte de cosas, hasta el punto que se produce su banalización, al incorporarse en medio de una urbanización con su correspondiente jardín, conociéndose únicamente de forma genérica, por parte de la sociedad, acuñándose expresiones como de estas hay muchas por la costa. Sin embargo, las épocas en las que se construyeron, las tipologías, plantas, remates, técnicas constructivas y en algunas hasta su decoración, nos permitiría individualizarlas por encima de esa generalización. (Figura 2)

Desde ese momento en que la sociedad concibe este patrimonio como algo seriado, repetitivo, el contexto 
territorial ha desaparecido de la imagen de ésta, quedando como un elemento puramente testimonial y acotado a un espacio concreto. Si no nos apoyamos en una lectura territorial más compacta, sacando a la luz parte de estos elementos tan característicos de los territorios medievales y de la Edad Moderna, ese patrimonio quedará desprovisto de una mirada más amplia. Por ese motivo, dentro del marco de las políticas culturales trazadas para el patrimonio, sería conveniente la elaboración de acciones que supusieran un paso más en la consecución de un producto de mayor calado y significación social, dejando por unos instantes, a un lado, la visión específica de monumento, por otro lado poco operativa en cuanto a devolución de significados, respecto a la situación especial de este patrimonio, para avanzar un paso más, además del estrictamente conservativo, logrando proyectar sobre el territorio la importancia de ese lenguaje como testimonio evidente de un intenso período en el tiempo ya lejano. Las actuaciones en pintura mural no pueden ir por el camino de la monumentalización, porque si no se perdería el carácter global de la presencia de esa manifestación en la ciudad.

Existen diversas formas de recabar la atención de la sociedad respecto a la frágil situación del patrimonio, una de ellas ha sido la propuesta del pintor Eugenio Chicano bajo el título, Las Torres Almenaras de la Costa Oriental de Málaga, serie expuesta recientemente, que valoramos como una muestra de esa imbricación de sensibilidades entre el arte contemporáneo y el patrimonio. Pero nuestro interés se enfatiza al servir de puente entre pasado y presente de esas torres en el territorio de Málaga, valiéndose de la fuerza de unos recursos plásticos que nos transmiten una primera idea del paisaje, otorgando un protagonismo casi absoluto a las torres, utilizando la luz, el contraste de las formas y los colores para construir ese horizonte que toma como inspiración un segmento del territorio, expresado de forma sagaz. En definitiva, Chicano ha sabido conectar de manera íntima esos recuerdos a través de la indagación por los territorios de la memoria 6. (Figura 3)

Luego de esta introducción sobre la importancia del lenguaje en el territorio, nos vamos a referir al lenguaje que configura, o que puede configurar la imagen de la ciudad de Málaga, teniendo en cuenta todo lo dicho, en un territorio urbano, y en una cronología precisa, siglo XVIII, y la posibilidad de su recuperación, implicando distintos ámbitos de la ciudad. La pintura mural, sobre todo la que ha nacido en el exterior de los inmuebles, a diferencia de los interiores, presenta una fuerza y potencialidad de significados, que deben estar presentes en el paisaje del nuevo equipamiento cultural de la ciudad.

\section{Caracterización y ámbito territorial de la pin- tura mural}

A lo largo de los tres últimos años hemos trabajado en un Proyecto de Investigación, y tras su conclusión

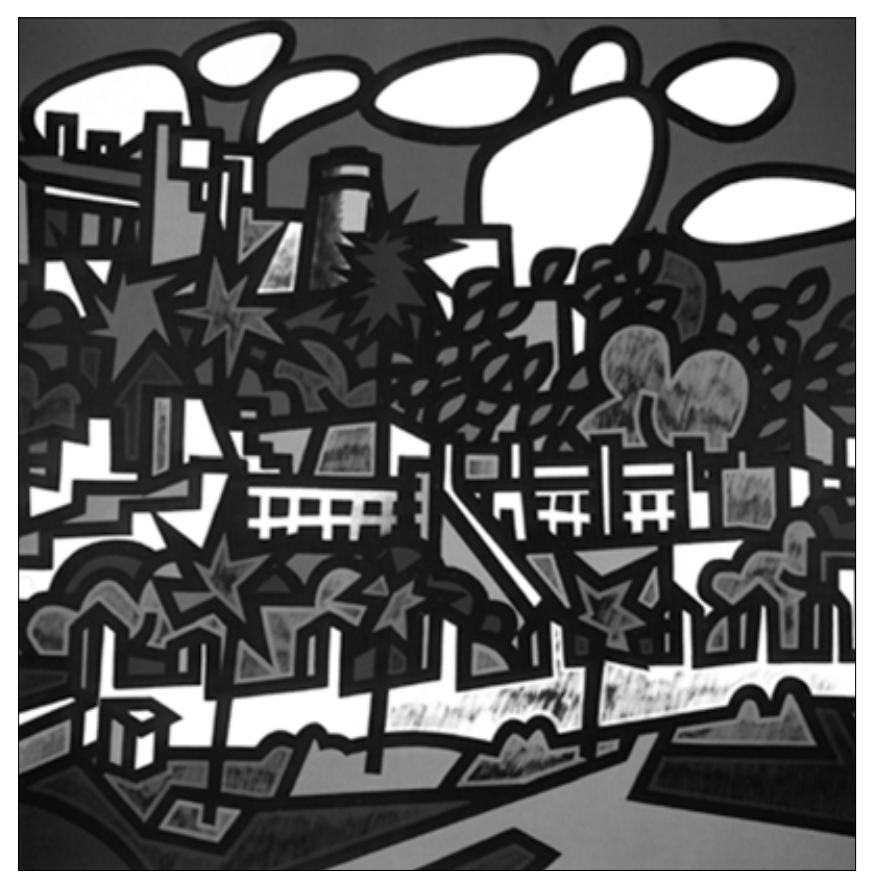

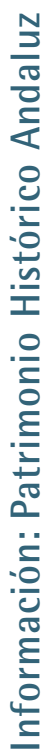

hemos comenzado a abordar la segunda fase, que arranca de la experiencia anterior ${ }^{7}$, pudiendo constatar el cambio de signo que la presencia de la pintura mural ha provocado en la imagen de la ciudad, llamándonos la atención, a la vez que causaba nuestro asombro. (Figura 4).

Y en ese sentido, el inventario llevado a cabo en el Proyecto de Investigación, se ha erigido como la herramienta más eficaz para el control exhaustivo del territorio urbano de las arquitecturas del color. Partimos de un inventario inicial, en papel, en donde reseñamos, someramente, muchas de las casas desaparecidas, que también forman parte del recuento final. La calle y el número de la vivienda, las plantas y el motivo ornamental eran los únicos datos que poseíamos. Cerca de medio centenar componían ese primer acercamiento, que aparecía claramente dividido en varias zonas, englobando una parte importante de la ciudad.

Tras iniciarse el Proyecto se trabajó desde dos líneas, una de ellas el desarrollo de un instrumento en Foto 4: Mapa de la pintura mural de Málaga. Siglo XVIII

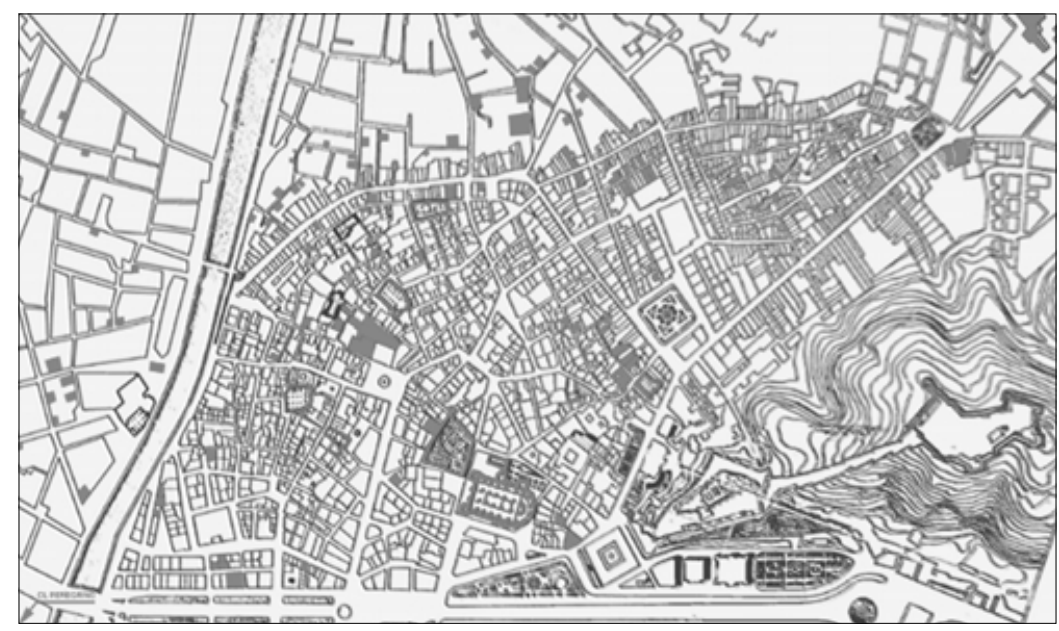


soporte informático que permitiera volcar la información obtenida. Esa aplicación debía ser ágil y flexible, con suficientes campos textuales, dada la peculiar situación de este patrimonio, sujeto a ser pormenorizado en los comentarios. El salto conceptual fue grande, del papel a la informática, no sólo por la vocación patrimonial con la que había nacido el proyecto, sino por la trabazón de su estructura, no dejando de lado los aspectos dedicados a la conservación ni a la protección, además de la datación histórica. La labor del profesor Isidoro Coloma fue determinante en este trabajo (Figura 5). Desde un principio se vio la necesidad de describir por inmuebles del que colgarían las distintas fichas individualizadas que harían referencia a cada uno de los motivos ornamentales que componían la decoración, logrando con ello un trabajo preciso para futuras investigaciones de mayor proyección. La otra línea de trabajo partía del barrido de la ciudad por parte de un equipo de cuatro becarios. Para llegar a buen puerto había que desarrollar una metodología de trabajo, basada en la forma de reconocer la pintura mural. Para ello se hicieron diferentes salidas a la ciudad, que tuvo como objetivo esencial identificar unas tipologías arquitectónicas, comenzando a adiestrar y a educar la mirada, ya que la pintura mural aparecía como pequeños testigos en las fachadas de los inmuebles, y lo que hacía aún más difícil este trabajo era la infinidad de capas de cal que ocultaban los motivos, el fuerte cableado, así como los bajantes que tapaban o rompían la estructura de la composición.

Sin lugar a dudas, y después de haber puesto en marcha el inventario, el resultado final ha sido sumamente satisfactorio, se ha duplicado la cifra inicial, pero lo más importante es que se ha descubierto un ámbito territorial de pintura mural en Málaga, que comparte una extensión que implica toda la ciudad. Desde entones, pudimos observar que había claramente una pauta común, la presencia de este lenguaje esta-

Foto 5: Ficho tipo del inventario de pintura mural de Málaga

\section{ARQUITECTURA PINTADA EN MÁLAGA Y MELILLA. Siglos XVI-XX} Descripción

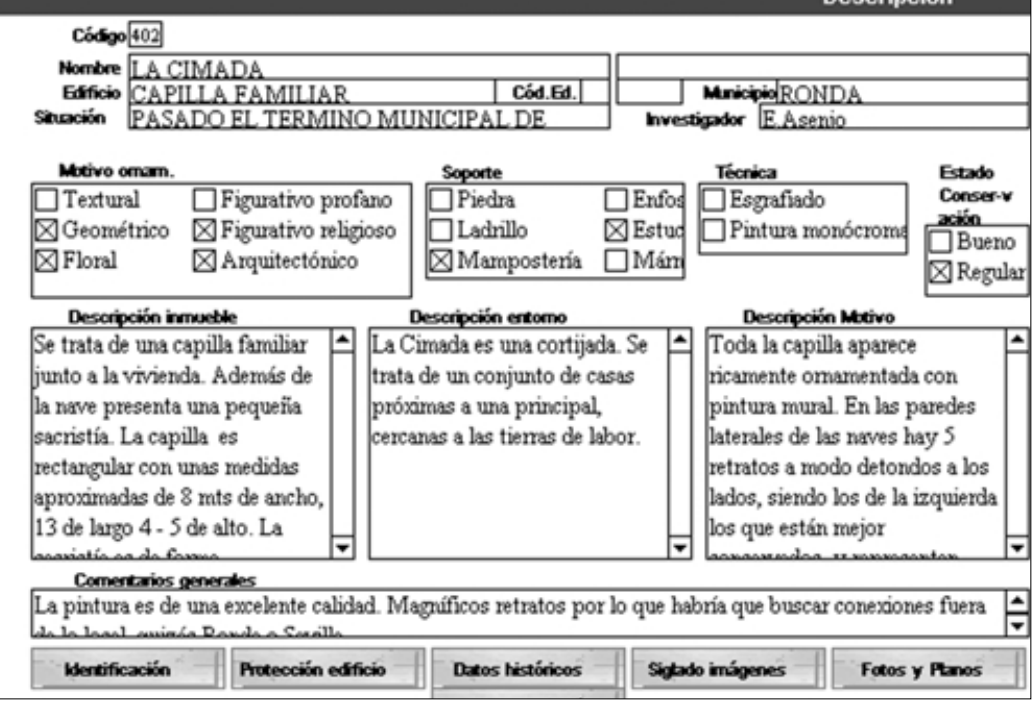

una moda, la ciudad comenzaba a abordarse desde otros presupuestos, como era la construcción de una imagen desde lo efímero. Este feliz encuentro nos permitía hablar de pintura mural y ciudad, en detrimento de pintura mural, Centro Histórico y Conjunto Histórico. Esto planteaba, realmente, una seria preocupación, que abordaremos en el último apartado, dedicado a la protección.

Lo que sí es cierto, es que no podíamos aventurarnos a decir que un espacio respecto a otro poseía unas connotaciones especiales, pues la riqueza de esta manifestación se expresa precisamente por medio de la pluralidad de sus componentes. Es verdad que en los inmuebles, civiles y religiosos, se agolpa un acopio mayor, aún si cabe, que en el resto de la arquitectura tradicional. De hecho, mientras en el primer grupo existe una predilección, en la mayoría de los casos estudiados, por desarrollar un programa que ocupa la totalidad de las fachadas, en el segundo, lo característico es la distribución seleccionada en determinadas áreas del paramento, enfatizando el recercado de las ventanas y los balcones.

Prácticamente, la casi totalidad de la pintura mural de Málaga es de autor anónimo. Esto plantea otro considerable problema para una sociedad que no está acostumbrada a valorar lo no documentado ${ }^{8}$. Y es que la tradición, en cuanto a transferencia de información se refiere, como medio para apreciar las manifestaciones de la cultura se ha resuelto la mayoría de las veces, sobre la base del autor y la fecha de la obra, prescindiendo, a menudo, del contexto, que es precisamente uno de los mayores atractivos de las arquitecturas pintadas. Por lo tanto, debemos indagar otros campos y otros conceptos, que tienen que ver más con la expresión de la globalidad frente al determinismo de lo particular.

No obstante, la escala de este territorio urbano ofrece unos hitos, palacios y casas de un sector acomodado de la población, que en unión a otros inmuebles pueden ser fechados, como ya hemos apuntado en otras colaboraciones?.

La pintura mural de Málaga está llena de caracterizaciones que nos obligan a desentrañarlas, reclamando nuestra atención, y que resumimos en las siguientes: - Esta manifestación representa dentro del contexto cultural de la ciudad, en este caso durante el siglo XVIII, como ya hemos apuntado, uno de los estadios de mayor nivel expresivo alcanzado por una sociedad, que se manifiesta por medio de un lenguaje ornamental de carácter heterogéneo, que resumimos en cinco tipologías: figurativo, floral, arquitectónico, geométrico y textural. (Figura 6).

- Se presenta de manera constante al integrarse en el diseño de algunas de las fachadas de los inmuebles de esta ciudad. Esto nos permite singularizar unas tipologías arquitectónicas, cuyo rasgo diferenciador del resto, va a ser el hecho de poseer esta connotación matérica, que se traduce en el uso de colores, como amarillos y rojos, en mayor me- 
dida, frente a verdes y azules, reservados para elementos de decoración geométrica y floral, y el negro para dibujar el contorno de las figuras.

- La pintura mural se convierte en un instrumento de cambio en la ciudad, desde el uso de un material frágil, realizado sobre un revoco fresco al que se le solía pasar un punzón para trazar el dibujo, como se puede observar todavía en algunas decoraciones, al que se le añadía el color. Si en épocas precedentes, siglos XVI y XVII, el cambio de estructuras, como la transformación de la ciudad árabe en cristiana había llevado a soluciones que implicaban la desaparición de la primera, la diferencia, en este momento, se marca al transformar una arquitectura preexistente o de nueva creación, dotándola de forma y color.

- La fiesta constituye un recurso sumamente efectivo del que arrancan muchas de estas construcciones ilusorias, siendo las del Corpus Christi, las frecuentes canonizaciones durante la Edad Moderna, y la fiesta de los patrones San Ciriaco y Santa Paula, las que pudieron dejar, entre otras, una huella de mayor calado.

- Constituye un lenguaje de signos dentro de la ciudad que permite vehicular, a veces, un mensaje, mediante el desarrollo de un programa, mientras que, otras tantas, se convierte en imágenes que más que imitar una moda, la asumen como estructura de permanencia, pero en definitiva, lo que hace patente es el uso prolongado de una materialidad evidente.

- Su ubicación estratégica en el territorio urbano, en los distintos espacios de la ciudad, comporta un significado muy diferente a la situación del resto de los edificios. Por ejemplo, la nueva ocupación, que de manera continua se hace de la calle de Carreterías, sobre todo desde comienzos del siglo XVIII, cuando la antigua zanja se había convertido en muladar y el cabildo municipal cedió las tierras a cambio de su ocupación y acondicionamiento, dejándonos como signo evidente de esa transformación la fachada del palacio del marqués de Valdeflores ${ }^{10}$, a mediados del siglo XVIII. De su decoración sólo queda un pequeño fragmento, pero que nos permite adivinar una composición de mayores pretensiones, que bien pudiera resolverse su significado en el papel que la imagen y el poder detentaba la nueva nobleza de Málaga, frente a otras, en donde el uso de esa materialidad aplicada a la superficie significaba el deseo de trocar lo viejo en algo nuevo. (Figura 7).

- Aparecen como un conjunto en donde el uso del color nos transmite un armónico y sutil juego lumínico que debió crear un ambiente decididamente sofisticado, que reunía la tradición mudéjar, como estructura de permanencia que pervive durante el siglo XVIII, con el repertorio clásico, asimilados e integrados, formando parte de un mismo paisaje.
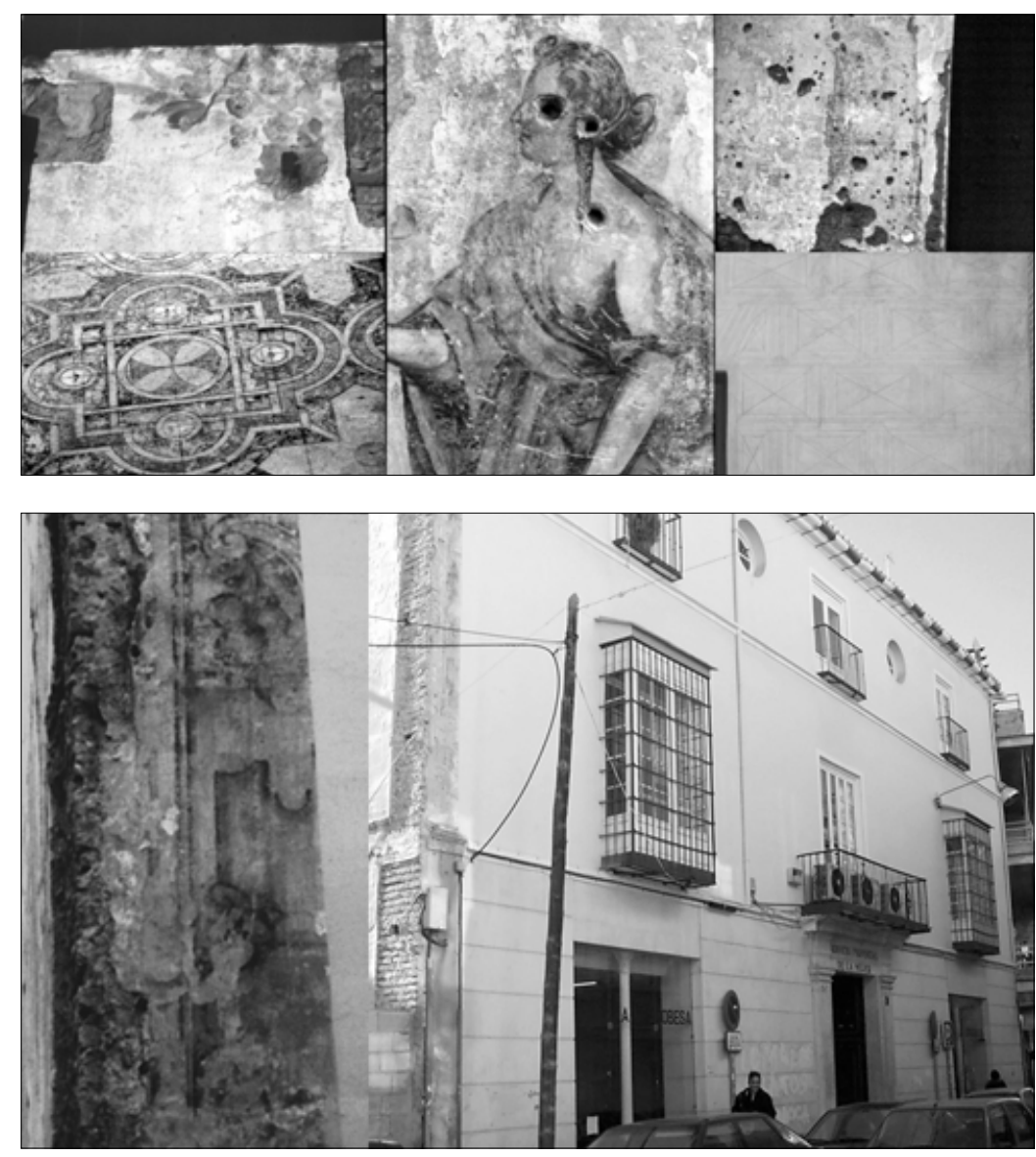

- La pintura mural presenta un rasgo diferenciador, que la convierte en un signo que debe ser parte significativa de la memoria de la sociedad, debido a la importancia que el encuentro, intercambio y devolución de significados a la ciudad produce la percepción del conjunto global de su iconografía. Prácticamente el 95\% de las representaciones de las fachadas, no obedece a una temática religiosa, por lo que, bajo un punto de vista más aperturista, podíamos decir que asistimos a un cambio de la imagen de la ciudad, en donde pesa más lo civil, teniendo en cuenta que todavía nos encontramos en una ciudad conventual, cuyos espacios públicos son compartidos con capillas, retablos callejeros, balcones, etc., permitiéndonos ampliar y precisar más aún su significado en el contexto urbano, y sobre la constante mutación del gusto de la sociedad barroca. Por lo tanto, en ese momento la ciudad se compartimenta, se dualiza su imagen de forma más enriquecedora a como la habíamos considerado hasta hace escasos años.

- En cuanto a la valoración final de la extensa y abigarrada presencia de la pintura mural en la ciudad actual supone un viraje de $180^{\circ}$ para su conocimiento, que pone en solfa muchas de las generalizaciones que la historiografía antigua y moderna, hacía tiempo había determinado para la ciudad de Málaga, logrando desde esta postura recuperar visiones emblemáticas de lo antiguo frente a otras miradas excluyentes de lo viejo $"$.
Foto 6: Tipologías ornamentadas de la pintura mural de Málaga

Foto 7: Málaga. Vista general y detalle de la fachada del Palacio de Valdeflores 
Una vez expuestas algunas de las características que nos pueden ayudar a conocer y a valorar la pintura mural, debemos atender a otro aspecto igualmente interesante, tal es la lectura de la ciudad como un texto narrativo, cuyo lenguaje, los diferentes elementos patrimoniales -en este caso no reconocidos-, aparecen desordenados, y es desde el conocimiento y la investigación como podemos poner orden y estructura a ese lenguaje, es decir, a los elementos que componen e intervienen en ese proceso. La pintura mural es un capítulo dentro de la ciudad, y como tal está llena de sutilezas, es un tejido primoroso que hay que saber tratar. Si actuamos a la ligera, sin una metodología determinada, el texto quedará sin fuerzas y brutalmente destrozado. $Y$ tampoco es justo que apoyemos toda la valoración de la pintura mural en los monumentos que portan este lenguaje, porque entonces estaríamos falseando la dimensión real de esta parte de la cultura de Málaga.

La reciente actuación y consiguiente recuperación de la fachada de la Iglesia de San Juan ha sido un acontecimiento para la ciudad, entre otras cosas, porque:

- Se ha actuado sobre un espacio que desde diferentes perspectivas de la ciudad asomaba la imagen blanqueada de su fachada, que desde hace años dejaba ver pequeñas secuencias de su esgrafiado, a modo de despiece de sillares, así como un dibujo inciso de forma geométrica. (Figura 8).

- Se consigue desde esta recuperación integrar la pintura mural, que no las intervenciones realizadas únicamente a través del color, para mostrar un inmueble de una considerable dimensión, enclavado en una de las arterias comerciales de la ciudad, recorrida por numerosos malagueños y visitantes que buscan en ella lugares de la memoria. A partir de ahora se convierte en un signo que en unión a otros, como la cercana fachada del inmueble de

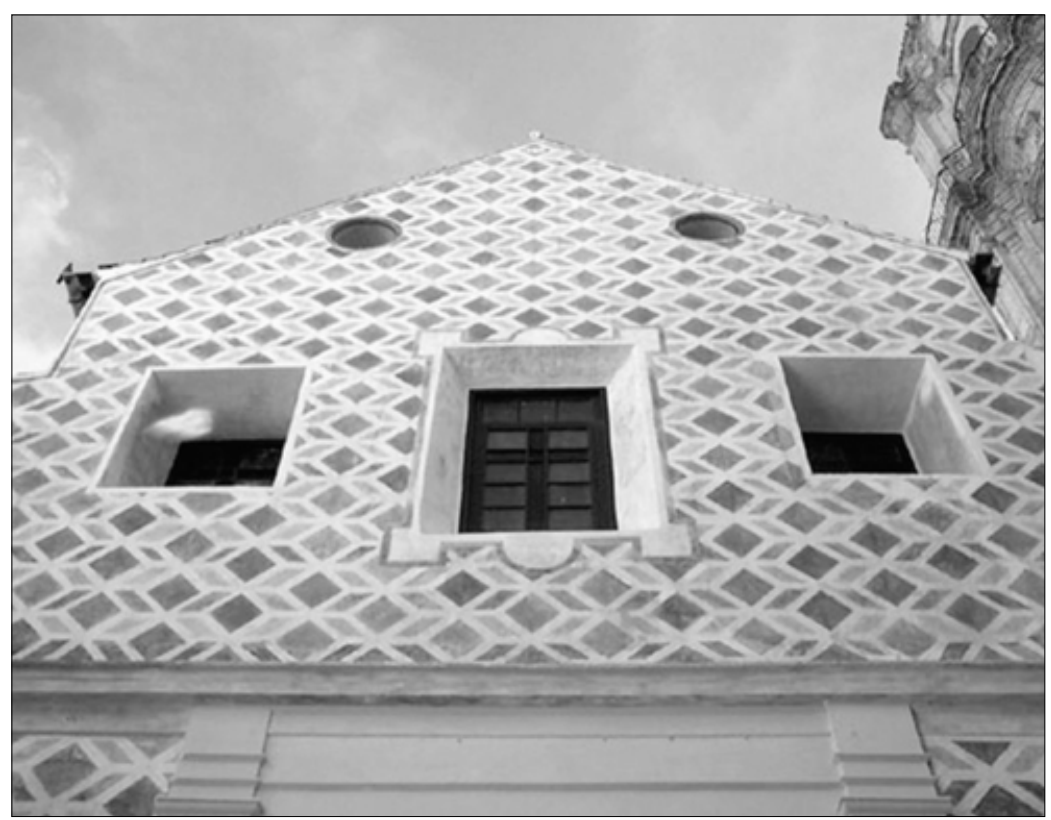

calle Hornos, recientemente recuperada, forman ese lenguaje sistémico, al que debe aspirar toda ciudad.

- Hay que valorar la incorporación de estas fachadas con su decoración al completo a la escenografía urbana. Es una situación muy diferente a la de muchas de las casas hasta ahora inventariadas de las que solamente se llega a ver pequeños fragmentos, como por ejemplo el Palacio de Villalcázar que solamente conserva la pintura en la fachada lateral de la calle D. Juan de Málaga, siendo ésta la tónica general.

La reflexión sobre la ciudad, por parte del municipio, su decisión de intervenir implica sensibilidades próximas al reconocimiento de un pasado urbano, rico, diversificado, y lo que es mejor aún, capaz de formar y suscitar en las nuevas generaciones, y en los de mayor edad, una conciencia que implica su aprehensión como parte de su cultura. Por todo ello, ya no nos quedamos en las grandes etapas de la historia, que durante años la investigación ha tenido que sedimentar y colmatar lagunas, pues ahora nos encontramos en el momento idóneo para ir completando parcelas que van más allá de actuaciones singulares de arquitectos, pintores, reconocidos y valorados ${ }^{12}$. Avanzamos, por tanto, un paso más en una sociedad, como la malagueña, que ha decidido regenerar miradas extensivas sobre su legado cultural.

\section{¿Defende, proteger, conservar?}

La dinámica que presenta este patrimonio no resulta muy distinta a la de otros, únicamente cambian las formas, la problemática que genera el entorno en donde se ubican, y el grado de asimilación por parte de la sociedad. A lo largo de toda esta exposición hemos querido dejar constancia de la relevancia de esta materialidad, al mismo tiempo que poníamos el acento sobre las características del color de esa piel de la ciudad antigua. No es la única, aunque sí de las más desfavorecidas en cuanto a la forma de protegerlas, puesto que parece obvio que al formar parte de la arquitectura queda garantizada la conservación, pero esto solamente sucede cuando el inmueble se encuentra bajo los efectos de la protección integral, ya que el resto de las protecciones arquitectónica, grado I y || son más permisivas en cuanto a los criterios de actuación, aunque en ellas tienen perfectamente cabida la conservación de estos elementos, siempre y cuando los profesionales sean sensibles a este hecho. Pero aún así, tendríamos que ver para el caso de Málaga las intervenciones tan dispares entre unas pinturas murales y otras, para darnos cuenta de la ausencia de una metodología que evidencia la carencia de unos criterios globales, que traduce, finalmente, la no-comprensión significativa de estos elementos. De este modo, la protección resulta muchas veces ineficaz si no se acompaña, a la hora de intervenir, de unos criterios válidos que implementen el significado de este patrimonio dentro del 
contexto cultural que comparte con otros patrimonios urbanos.

Estos tres términos expresados de forma consecutiva, son acciones propias que desencadenan una voluntad inicial, la preocupación por parte de un sector social, de algo que se les escapa. Estas acciones son cruciales para reanimar el factor decisivo que puede tener una sociedad cuando forma alianzas a favor de la protección de la cultura.

Las cosas cuando se cuentan de forma imparcial poseen esa especial característica de la exageración, sin embargo, nuestro balance y nuestra postura, después de trabajar para que se reconocieran los valores patrimoniales de las arquitecturas pintadas, siempre ha sido lograr un camino intermedio, aún así, y respecto a la situación de éstas, podemos decir que está cambiando en estos últimos años. Aunque los años finales de este siglo han estado marcados por la desaparición prematura de algunos de los inmuebles que poseían pintura mural a un ritmo acelerado, también podemos decir que a raíz del encargo del Plan del color del Centro Histórico en 1997 al arquitecto Joan Casadevall existe una conciencia abocada a poner el acento en los porqué y en los cómo debe ser conservado este patrimonio, aunque todavía siguen desapareciendo muchos inmuebles de forma indiscriminada 13 , teniendo en cuenta que estos ya no podrán ser renovados.

La reflexión, en cierta medida, ha venido desde la incorporación de este Plan sobre el color de la ciudad de Málaga, poniendo de relieve la sensibilidad de la administración municipal al abordar la recuperación de la imagen de la ciudad a través del color, aunque hay que señalar al respecto que no se trata de una experiencia aislada 14. Desde los años ochenta se viene recuperando la imagen degradada de diferentes ciudades con campañas promocionales, como en Barcelona, y ya en los años noventa Granada, Málaga y Valencia también se han incorporado a esa recuperación. El cómo se ha hecho o la instrumentalización del plan para orientarse hacia la rehabilitación de unas zonas en detrimento de otras, es lo que las diferencia.

La respuesta a la pregunta que inicia este epígrafe no está exenta de matices, ya que por un lado se ha producido un excesivo lastre y desgaste al no tener un proyecto global sobre el sentido de la permanencia de estas estructuras en la ciudad de hoy. Para que formen parte de la identidad de una sociedad contemporánea, como la nuestra, es preciso que además de ser tutelado por los diferentes agentes que intervengan en ese proceso, es del todo necesario que la sociedad lo recepcione como algo vivo, necesario en la dinámica de sus vidas. Empero, para lograrlo hay que cuantificar qué tenemos, qué medidas de protección poseen, y qué podemos hacer con lo que nos queda, entre otras preguntas.

En ese orden, intentamos replantearnos la situación de partida, ya valorada anteriormente. Tenemos cerca de cien calles en toda la ciudad de Málaga, con aproximadamente 134 inmuebles, recogidos en un CD Multimedia 15, en donde se ubican distintos fragmentos de pintura mural, cuyas características ya han sido expuestas. Heterogeneidad cultural son conceptos que resumen esta apreciación.

La siguiente pregunta se refiere a la protección. Para contestarla hay que pormenorizar. En este conjunto de calles existen áreas en donde la semejanza constructiva, y a veces decorativa, tiene un sabor genuino. Adentrándonos en esas zonas concluimos que en alguna de ellas existen áreas homogéneas de pintura mural, con cuatro, cinco y hasta siete casas, formando pequeños territorios urbanos de menor escala.

Los principales problemas planteados en esas áreas identificadas en C/ Tomás de Cózar, Hinestrosa y Nuño Gómez, podemos precisarlas en las siguientes:

- La ubicación en zonas de la ciudad que han alcanzado un alto riesgo de degradación (abandono, estado ruinoso, especulación, etc.)

- La casi ausencia de medidas protectoras de estos inmuebles en el Plan General de Ordenación Urbana, (P.G.O.U.), y en el Plan Especial de Protección y Reforma Interior del Centro Histórico, (P.E.P.R.I.C.H.)

- El fuerte deterioro de las fachadas, con una pérdida acelerada del revoco y el color.

Nos vamos a detener en dos de estas zonas para analizar algunas de sus peculiaridades:

Las casas pintadas de C/ Hinestrosa y las de Tomás de Cózar, la primera con siete y la segunda con ocho inmuebles pintados, se presentan como áreas sumamente degradadas, con algunos edificios clausurados y otros en estado ruinoso. La documentación técnica de los expedientes de la Iglesia de Santiago y el Teatro Municipal Miguel de Cervantes de Málaga, para la declaración de Bien de Interés Cultural (B.I.C.), nos ha posibilitado adentrarnos en la problemática del establecimiento de los entornos, apoyados, metodológicamente, en el análisis de la evolución histórica de la parcela, la configuración volumétrica de los inmuebles, la relación de las visuales, y la inclusión de edificios con destacados valores, entre otros. Esto nos permite tras su justificación, dar protección a los inmuebles que poseen pintura mural adyacentes a estos monumentos. Teniendo en cuenta que la $\mathrm{C} /$ Hinestrosa no tiene ningún inmueble en el Catálogo de edificios protegidos del Plan, a diferencia de la C/ Tomás de Cózar que a seis de los ocho inmuebles se les otorga la protección arquitectónica grado II, lo cual permitiría que si se tiene que hacer algún tipo de obra en esos inmuebles se tendrá que informar a la Delegación Provincial por ser competencia de ésta la custodia de los B.I.C y sus entornos.

De lo particular a lo general, si ésta es la situación de las áreas homogéneas, ¿cual será la de aquellos 


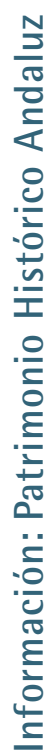

Foto 9: Mapa de pintura mural con Protección Integral y Arquitectónica de Grado I y II

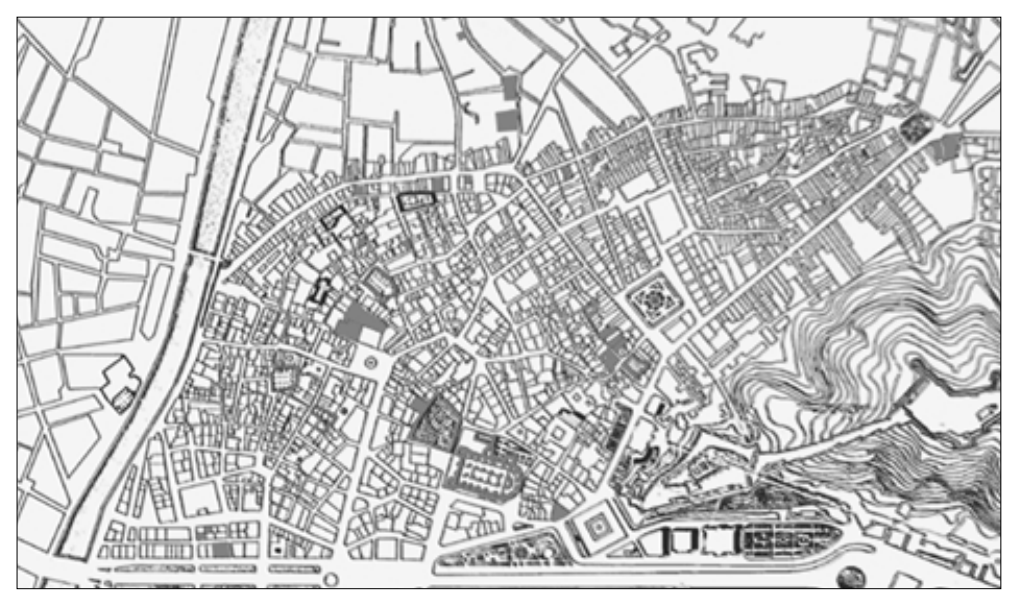

- Por un lado, la acumulación de una cantidad importante de edificios en los bordes y en la cerca histórica y más allá de éstos, dejando un significativo patrimonio desprovisto de protección, a no ser que se trate de una iglesia, como la de San Felipe Neri, entre otras, ya que el resto de las casas aledañas, prácticamente no tienen esas medidas de salvaguardia. Si a ello unimos el gran vaciado que se está produciendo de esa zona, tenemos las condiciones idóneas para no dejar huella.

- Las pinturas que se conservan en el interior del ámbito de protección evidencian las mismas carencias del apartado anterior, amparándose en la declaración de ruina, como vía rápida para dar salida a unos inmuebles en desuso. Y sobre la base de que las licencias de declaración de ruina las gestiona el ayuntamiento, $y$, además, como lo que no está protegido en el catálogo urbanístico no es preceptivo comunicarlo, desaparecen sin más. Al fin y al cabo, piensan algunos, se elimina lo viejo de la ciudad.

- El principal problema que plantea todo diálogo es hablar un mismo idioma, y desde el Proyecto de Investigación se ha hablado de ciudad frente al concepto de Conjunto Histórico y de Centro Histórico. Y eso es así, entre otras cosas, precisamente por la amplitud, magnitud y extensión en toda la ciudad de un hecho, como este recurso pobre ante la precariedad de medios para costear materiales de mayor dispendio, y la posibilidad de construir significados desde un lenguaje mucho más económico, como la pintura mural, acorde con ese programa de renovación urbanística que se instala en la ciudad durante el siglo $\mathrm{XVIII.}$
Esta figura jurídica de Conjunto Histórico podría haber sido un instrumento eficaz si se hubiera recogido el patrimonio de la ciudad desde la madurez y la valoración, pero en la práctica se ha demostrado lo contrario, apareciendo instrumentalizada por otros intereses, que no entiende de realidades históricas, cotidianas, ni de espacios fronterizos, que ni siquiera ante la secuencia monumental del conjunto de Santo Domingo en esa área, próxima al límite actual de la delimitación, quedó protegida.

- La situación de los barrios del Perchel y de la Trinidad merece un tratamiento especial, como es la particular política llevada a acabo desde un planeamiento previo al P.G.O.U y al P.E.P.R.I.C.H., que prácticamente no ha dejado testimonios de pintura mural, a excepción de la denominada Casa del Obispo y el inmueble de calle Calvo y el camarín de la Virgen de la Aurora. El resto que aparece en el mapa del CD Multimedia corresponde a casas del primer inventario realizado.

La cuantificación de los inmuebles con las distintas protecciones que poseen nos darán la última visión sobre este apartado. Desmenuzando el valor numérico arriba señalado, 134, obtenemos:

- Plano de Protección Integral con 18 inmuebles, que obedecen tipológicamente hablando a 12 edificios religiosos, (iglesias y otros antiguos establecimientos conventuales, luego transformados en otros usos), y 6 palacios.

- Plano de Protección Arquitectónica I: 7 inmuebles que son 4 viviendas, 2 palacios y un antiguo recinto conventual, hoy colegio.

- Plano de Protección Arquitectónica II: II inmuebles que son 10 viviendas y un edificio, antiguo claustro, también colegio. (Figura 9)

- Plano de edificios Sin Protección y Desaparecidos: 57 inmuebles, el primero, todas viviendas, y 4I, el segundo, entre viviendas, palacios y otras tipologías. La particularidad de este último ejemplo está en lo metafórico de algunos casos, como la eliminación del inmueble, salvaguardando la pintura mural del edificio de calle San Jacinto, o la permanencia de la Casa del Postigo de Juan Bollero, interviniendo en la remodelación de la fachada, pero al no estar protegido ha desaparecido la pintura mural. (Figura I0-II)

La última pregunta que nos planteábamos es qué podemos hacer con lo que tenemos. La respuesta la hallamos en la peculiar situación y característica que poseen estas casas. Nuestra propuesta se dirige a la potenciación de un lenguaje urbano de pintura mural, que presenta objetivos precisos, ya enumerados en esta exposición. Por otro lado, dada la voluntad política de favorecer algunas intervenciones, creemos oportuno definir conceptualmente unos criterios en pintura mural, que recojan esos valores, los 
cuales deben servir de base para las actuaciones que se realicen.

Esos criterios, como marcos generales, los resumimos en:

- Un examen y reflexión conceptual del patrimonio, atendiendo a la especial situación de la ciudad, y el reconocimiento a la expresión de la diversidad multicultural.

- La aplicación de la carta del color en otras áreas fuera del ámbito del centro histórico, lo que supondría un reconocimiento a ese lenguaje de signos.

- La recuperación de la pintura mural debe indagar en la cualificación formativa de especialistas, de lo contrario se produce disparidad de criterios, acudiéndose en no pocas ocasiones al repinte, con el consiguiente problema a nivel de conservación, como ha ocurrido en las pinturas de la fachada de la iglesia de San Julián y la Casa de Niños Expósitos ${ }^{16}$, por citar casos.

- El estudio pormenorizado del entorno, analizando las causas que producen el deterioro, ya que las pinturas forman parte de un contexto urbano, y salvo casos excepcionales no debe separarse de aquel. Ante todo preferencia a la unidad.

En definitiva, y como conclusión, la pintura mural aparece escenificada en la ciudad. Con todo, ésta es entendida como un texto rebosante de párrafos, edificios, plazas, calles, etc., en donde las arquitecturas del color encuentran acomodo en ese texto, sobre la base de unos criterios de intervención que generen miradas sobre viejas estructuras, al mismo tiempo que proyectan visiones renovadas de las mismas. Así, además, podríamos apreciar que la ciudad se descubre ante nosotros de forma sorpresiva y bajo diferentes matices, que nos aproximan a un concepto de ciudad en el que tienen cabida la fuerza expresiva de otros recursos patrimoniales.
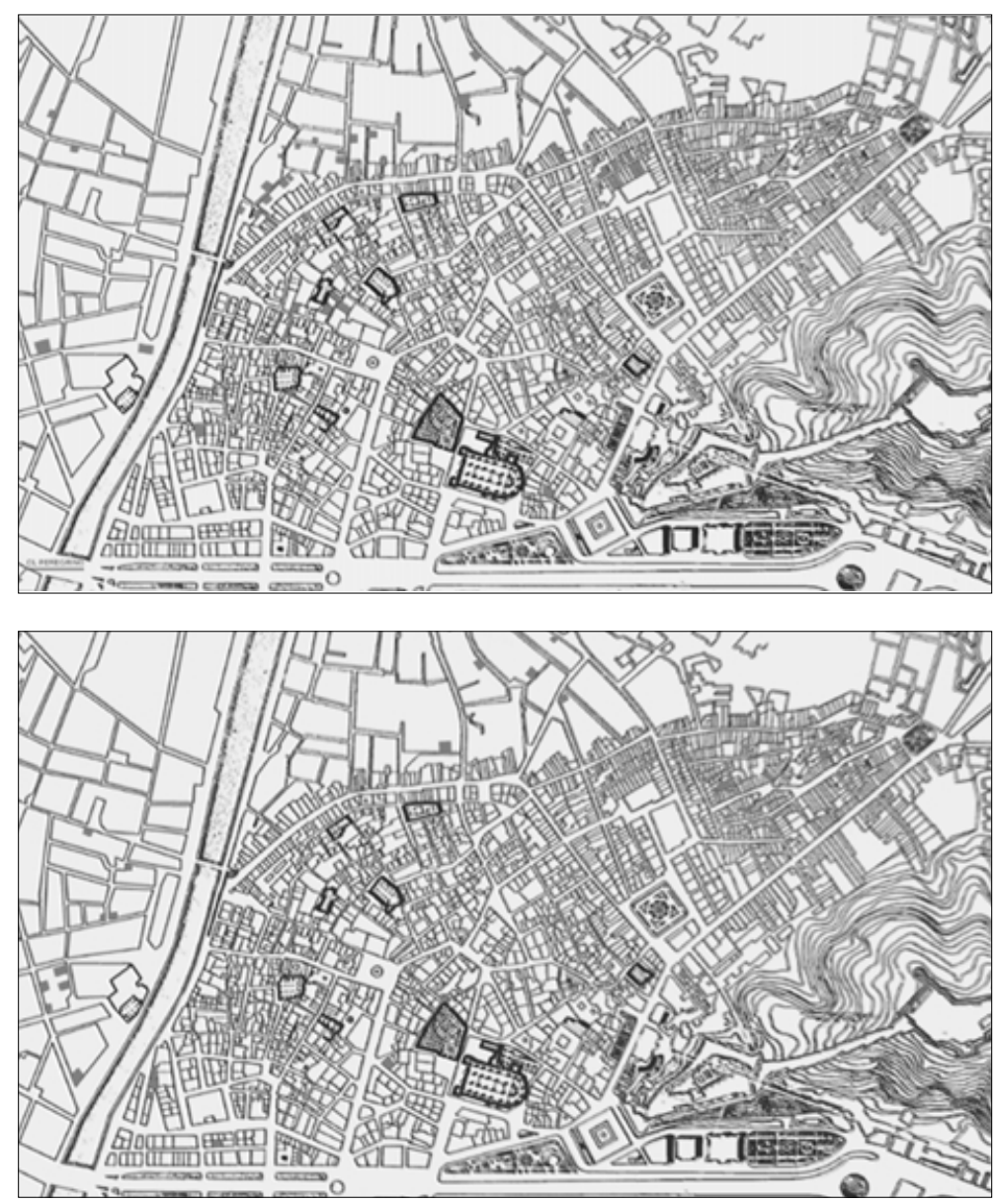

Foto 10: Mapa de la pintura mural sin Protección

En contadas ocasiones se pone al alcance de la sociedad la posibilidad de detenerse y observar de forma pausada y con atención, el efecto realmente magnífico de unas líneas y unos colores, que en constante suma ejecutan un programa capaz de vertebrar toda la ciudad, recorriendo sus fachadas, dando luz, pero sobre todo, imprimiendo carácter en un pulso constante entre la renovación de lo antiguo y la desaparición de lo viejo. mural. Desaparecida
Foto I I: Mapa de la pintura

\section{Notas}

I. Este interesante documento es fruto de un trabajo interdisciplinar, entre diferentes profesionales de la Consejería de Cultura, coordinadas por Víctor Fernández Salinas, profesor de Geografía de la Universidad de Sevilla, y publicadas por el Instituto Andaluz del Patrimonio Histórico. FERNÁNDEZ SALINAS, V (Coord.). Bases para una Carta sobre Patrimonio y Desarrollo en Andalucía, IAPH, Sevilla, 1996.

2. En este sentido, hay que recalcar que existen muchas formas de desaparición de determinados elementos de la cultura, no sólo material, muchas veces, involuntarias, como las que provocan las guerras, pero, quizás, la más peligrosa sea la desaparición significativa y el consiguiente olvido, ya que, si algunos de estos fragmentos de la cultura deja de interesar, entonces se pierde uno de los testigos imprescindibles para que el patrimonio sea social: la conexión entre la comunidad y en este caso el inmueble en donde se encuentran las pinturas.

3. CAMACHO MARTÍNEZ, R. Cuando Málaga no era blanca. La arquitectura pintada. Boletín de Arte de la Universidad de Málaga, n 13-14, 1992.

4. DE LA CALLE VAQUERO, M; GARCÍA HERNÁNDEZ, M. Ciudades históricas: patrimonio cultural y recurso turístico, Ería, $n^{\circ} 47,1998$

5. Queremos agradecer a la Fototeca del Laboratorio de Arte de la Universidad de Sevilla la facilidad para el acceso y repro- 
ducción de esta imagen. Agradecemos al Departamento de Técnicas Gráficas del IAPH la reproducción de esta imagen.

6. César Olano, arquitecto y académico de San Telmo, introductor del catálogo, define esta serie, como una "evocación de paisajes de la infancia". Exposición de Eugenio Chicano Torres Almenaras de la Costa Oriental de Málaga, celebrada en la Sala Italcable del 10 de noviembre al 5 de diciembre de 2000, Málaga, Fundación Unicaja, 2000.

7. El Proyecto de Investigación PB 95 - 0477 La arquitectura pintada en Málaga y Melilla. Siglos XVI - XX, nos ha permitido aprehender la lectura de la ciudad desde otros parámetros gnoseológicos, como el color histórico, realizando un inventario de Málaga, la Provincia y Melilla, adivinándose en todas ellas, la presencia de unos materiales que determinan la imagen de la ciudad en cada una de las etapas que marcan el desarrollo del Proyecto.

8. No hemos encontrado en los archivos de Málaga contratos ni condiciones acerca de estas decoraciones de las viviendas, pero en las Ordenanzas de Málaga (recopiladas en I 556 y publicadas en $|6| \mathrm{I}$ ), ya se regían las órdenes "que se a de tener en el pintar de las obras moriscas" y en las de pintura al fresco", detallando los procedimientos, así como cuando se trataba de "ymagineria en la pared". Por otro lado, el Padre Llordén, en su documentada recopilación de los pintores de Málaga, además de las detalladas condiciones para la decoración del Presbiterio de la Catedral por César Arbasia en el siglo XVI, y la que se realiza sobre ella en el siglo XVIII, aporta datos sobre algunos pintores doradores cuya labor se extendía a "estofar en línea de arquitectura", "imitar a piedra lapislázuli", "cenefas de jaspe", "fingir mármol con sus franjas", etc, que serían los maestros de estas obras, y así lo han entendido también otros autores. (Ordenanzas de la Muy noble y Muy Leal Ciudad de Málaga. I6 I I. Edición facsímil. Ayuntamiento de Málaga, Real Academia de Bellas Artes de San Telmo, 1999), fols. 104 - 105. LLORDÉN, A. Pintores y Doradores malagueños. Ensayo histórico-documental. Siglos XV-XIX. Ediciones Real Monasterio de El Escorial, 1959, págs. 74-75, 315, 321, 325-329 y otras. ARCOS VON HAARTMAN, E. (coord.). Retrato de la Gloria. Restauración Mayor de la Catedral de Málaga. Winterthur, Barcelona, 1999, pág. 50. AA.W. Pinturas murales y elementos pétreos del Instituto Vicente Espinel de Málaga. Junta de Andalucía, Dirección General de Bienes Culturales, 2000, pág. 19.

9. CAMACHO MARTÍNEZ, R. Op. cit. ASENJO RUBIO, E. El valor patrimonial de las pinturas murales de Málaga. Boletín de Arte de la Universidad de Málaga, n² 21, 2000.

10. En la actualidad este palacio alberga la sede del Instituto de la Mujer. Constituye otra muestra en materia de intervención de no valoración, dejando consecuentemente otro inmueble mutilado de toda su capacidad expresiva, a la vez que evidencia la falta de unos criterios conservadores y restauradores, respecto a este singular patrimonio. Al final lo que prevalece es la incapacidad por nuestra parte de poder allegar a la sociedad unos conocimientos globales, sobre todo en unos edificios, que precisamente destacan por la desnudez de su fachada al igual que el palacio de Villalcázar, cuando en realidad la severidad con que marcaban la horizontalidad de estas construcciones, nos permitía desde la recreación de estas escenografías narrar aspectos que traducían, en esencia, los modos de vida de una cultura que basculaba entre lo lúdico y lo religioso.

II. Teniendo en cuenta que se excluía lo viejo, porque era sinónimo de deterioro, cuando lo viejo comporta unas características sumamente interesantes de las que no debemos prescindir, como es la posibilidad de transformar esos conceptos, por otros afines, como el de antigüedad que entraña otros significados, sobre todo valorativos para la sociedad.
12. Durante años, una de las líneas de trabajo por parte de las administraciones culturales, tanto estatal, como autonómica, ha sido la organización de diferentes eventos en torno a la figura de un artista, movimiento, etc, lo que ha supuesto para la sociedad un encuentro con su cultura, y a veces, para otro importante número del público, el descubrimiento de aspectos desconocidos, por otro lado, determinantes en mucho de sus aspectos. No obstante, hay que señalar, que en la mayoría de los casos se ha hecho un excesivo hincapié en esas figuras archiconocidas, no dando cabida a otros elementos de patrimonio igualmente significativos. Alonso Cano, Velázquez, Murillo y Zurbarán, componen una excelente terna, pero también es cierto, que existen otros acontecimientos del pasado que precisan de una lectura cercana y renovada, como sucede con la pintura mural, ya que éstas no son meras decoraciones en los muros de los inmuebles, sino todo lo contrario, recuerdos de una arquitectura que no puede ser leída sin el apoyo textual de este recurso. Trascender a sus significados es una invitación a conocer el medio urbano en el que se desenvolvió la vida cotidiana de una comunidad. Es otra forma de acercarse y mirar al pasado de la ciudad.

13. En los últimos años, 1998 - 1999, son varios los inmuebles que han desaparecido, como en la calle Salinas, Postigos, Cinco Bolas, Hoyo de Esparteros, Parras, Plaza de Montaño, calle Viento, entre otras, así como la limpieza de la fachada de inmueble del Postigo de Juan Bollero. Estas actuaciones lo que demuestran es, todavía, la escasa sensibilización ante este patrimonio.

14. CASADEVALL SERRA, J. Estudio del color del Centro Histórico de Málaga. Málaga, Ayuntamiento, 1999. El estudio del color del Centro Histórico de Málaga parte, al igual que en otros lugares, de un intento de regenerar la imagen de los centros históricos. La valoración que hacemos desde el equipo, a pesar de algunos desajustes, es positiva. Sin embargo, en otras ciudades, como Valencia se ha optado por desmenuzar los barrios históricos del Centro Histórico, analizándolos, como el del Carmen que cuenta con su propia carta.

15. Este CD Las arquitecturas pintadas del barroco en Málaga surgió como la necesidad de invitar a la sociedad a conocer la peculiar situación de este patrimonio. Para ello, decidimos incursionar en las nuevas tecnologías que ponen a nuestro alcance un conjunto de herramientas que hay que traducir convirtiéndolas en un caudal de información sugerente, combinando música e imágenes. A partir de ahí podemos entrar en un plano general y de detalle de la ciudad que referencia las calles en un contexto urbano con bastante precisión, asociados todos esos inmuebles a una somera ficha, consignando datos sumamente expresivos, como la tipología arquitectónica y ornamental, así como el nivel de protección y la situación actual en la que se encontraban a la fecha de 1999. A este trabajo le acompañan dos apartados, uno, en donde reflexionamos sobre distintos aspectos de la pintura mural y otro, un recorrido desde la proyección de la mirada por la interesante geografía urbana de la forma y el color. Este producto es fruto de la labor del equipo del Proyecto de Investigación PB 95 - 0477, y ha sido realizado por Jesús Lanzas Burgos y Eduardo Asenjo Rubio.

16. Así como el caso de la iglesia de San Julián es lamentable, el de Niños Expósitos es diferente, y aunque con los repintes se salva la imagen, creemos que no es lo más adecuado, si bien hay que reconocer se han dejado algunos testigos que evidencian las texturas originales. 